УДК 005:37

\title{
ВПРОВАДЖЕННЯ ДУАЛЬНОЇ ОСВІТИ У ВИШІ: ПЕРЕВАГИ ТА РИЗИКИ
}

\section{ANALYSIS OF THE INTRODUCTION OF DUAL EDUCATION IN A HIGHER EDUCATION INSTITUTION: BENEFITS AND RISKS}

\author{
Довгенко Яна Олексіївна \\ кандидат економічних наук, доцент, \\ Центральноукраїнський державний педагогічний університет \\ імені Володимира Винниченка \\ ORCID: https://orcid.org/0000-0002-3254-8746
}

\author{
Яременко Людмила Іванівна \\ кандидат педагогічних наук, доцент, \\ Центральноукраїнський державний педагогічний університет \\ імені Володимира Винниченка \\ ORCID: https://orcid.org/0000-0002-1167-8744 \\ Яременко Юрій Вікторович \\ кандидат фрізико-математичних наук, доцент, \\ Центральноукраїнський державний педагогічний університет \\ імені Володимира Винниченка \\ ORCID: https://orcid.org/0000-0002-8465-7389
}

\author{
Yana Dovhenko, Liudmyla Yaremenko, Yuriy Yaremenko \\ Volodymyr Vynnychenko Central Ukrainian State \\ Pedagogical University
}

Стаття присвячена аналізу переваг і ризиків впровадження дуальної освіти у виші. Досліджено теоретичні особливості методичних аспектів управління інноваційними процесами. Розкрито особливості дуальної форми навчання, досвід Германії та вітчизняні тенденції впровадження дуального навчання. Проаналізовано особливості та тенденції впровадження дуальної освіти в Україні, визначено переваги та ризики. Проведено SWOT-аналіз впровадження дуального навчання: аналіз ризиків та можливостей, слабких та сильних сторін впровадження зазначеної системи навчання. Проаналізовано основні етапи концепції підготовки магістрів за дуальною фрормою здобуття освіти у Центральноукраїнському державному педагогічному університеті імені Володимира Винниченка. Результати проведеного SWOT аналізу можна реалізувати при розробці стратегії дуального навчання в університетах.

Ключові слова: дуальна освіта, концепція, стратегія, SWOT аналіз, ринок праці, освітня програма.

Статья посвящена анализу преимуществ и недостатков внедрения дуального образования в ВУЗе. Исследованы теоретические особенности методических аспектов управления инновационными процессами. Раскрыты особенности дуальной фрормы обучения, опыт Германии и отечественные тенденции внедрения дуального обучения. Проанализированы особенности и тенденции внедрения дуальной образования в Украине, определены преимущества и риски. Проведен SWOT-анализ внедрения дуального обучения: анализ рисков и возможностей, слабых и сильных сторон внедрения указанной системы обучения. По результатам SWOT-анализа разработаны проект концепции и стратегии подготовки магистров по дуальной фрорме получения образования в Центральноукраинском государственном педагогическом университете имени Владимира Винниченко. Разработанные концепцию, стратегию и результаты проведенного SWOT-анализа можно использовать при внедрении дуальной формы обучения в университетах.

Ключевые слова: дуальное образование, концепция, стратегия, SWOT-анализ, рынок труда, образовательная программа. 
The article is devoted to the analysis of the benefits and risks of the introduction of dual education in a higher education institution. The purpose of the articleis to develop the main components of the implementation management of dual education in universities, SWOT analysis, development of the concept and strategy of dual education. Reforming and modernizing education in Ukraine in the direction of European integration into the educational area involves the development and implementation of innovative educational systems and technologies. An urgent problem in the organization of the modern educational process is the introduction of such a form of practice-oriented vocational education as dual education. Solving the problem of modernization and reform of education is an urgent need. The introduction of a system of dual training opens new perspectives in improving the efficiency of vocational education. Theoretical and methodological principles of the formation of an innovative model of introduction of dual education in educational institutions and training of specialists in this form in a market economy, in particular, by domestic scientists, are insufficiently considered. In the process of research, there were used general scientific methods of cognition and observation, comparison, generalization, modeling, as well as SWOT analysis, the traditional method of development and implementation of innovations. Theoretical features of methodological aspects of management of innovative processes are studied. The peculiarities of dual education, the experience of Germany and Ukraine and domestic tendencies of the introduction of dual education are revealed. The features and tendencies of the introduction of dual education in Ukraine, benefits and risks are defined. SWOT analysis of dual education implementation (analysis of general characteristics of strengths and weaknesses, general external opportunities and threats) is conducted. Weaknesses and strengths of the implementation of this educational system, its threats and opportunities for the university are identified. The main stages of the concept of master's dual training in Volodymyr Vynnychenko Central Ukrainian State Pedagogical University are analyzed. The results of the conducted SWOT analysis can be implemented in the development of dual education strategies in universities.

Keywords: dual education, concept, strategy, SWOT analysis, labor market, educational program.

Постановка проблеми. Досвід країн 3 стрімким розвитком економіки, таких як Японія, Південна Корея, та інших, засвідчує, що пріоритетний напрямок інвестицій в людину $\epsilon$ не наслідком зростання добробуту держави, а його причиною. Результатом такої зміни напрямку пріоритетності інвестиційних вкладень та їх концентрації в освітній системі, за останні 10-15 років, є не тільки стрімкий розвиток технологій, а й підняття економіки та життєвого рівня населення до показників передових світових держав. Слід зазначити, що самі по собі, без зв'язку 3 виробництвом наука і освіта не є чинниками розвитку економіки. Наука продукує нові знання, освіта готує фрахівців з відповідними компетентностями для національної економіки країни, створюючи при цьому необхідні умови для зростання добробуту, але реалізація цих умов здійснюється лише у процесі виробництва.

Аналіз останніх досліджень і публікацій. Сьогодні проблемам інтеграції освіти, науки й виробництва, дуальної освіти присвячено багато праць як вітчизняних так і закордонних вчених: Абашкіної Н.В. [1], Амеліної С.М. [2], Мілл У. [3], в роботах яких розкрито сутність, становлення та проблеми дуального навчання у Німеччині. Бегма О. [4], Грін Л., Пансрілов Ю., Карлюк С. [5], Кримчак Л.Ю. [6], Кулалаєва Н.В. [7], Яковенко К.В. [8] та інші пропонують удосконалити взаємодію освіти, науки та виробництва країни шляхом створення освітньонаукових комплексів асоціативного типу із залученням підприємств та установ України.
Виділення невирішених раніше частин загальної проблеми. Слід зазначити, що теоретичні та методологічні засади фрормування інноваційної моделі впровадження дуального навчання у закладах освіти та підготовка срахівців, зокрема у педагогічних вузах країни, за цією фрормою в умовах ринкової економіки недостатньо розглянуто вітчизняними вченими. Тому актуальною проблемою організації сучасного освітнього процесу $€$ впровадження такої форми практико-орієнтованої професійної освіти як дуальне навчання. Впровадження системи дуальної підготовки фрахівців відкриває нові перспективи у підвищенні ефрективності професійної освіти.

Формулювання цілей статті. Метою статті $€$ розробка основних складових менеджменту впровадження дуального навчання у вишах, проведення SWOT аналізу, розробка концепції та стратегії дуальної освіти.

Виклад основного матеріалу дослідження. 3 метою підготовки творчого, конкурентоспроможного, сучасного фрахівця, першочерговим завданням навчальних закладів $€$ не тільки вирішення проблеми інтеграції науки та освіти, а й інтегрованість 3 виробництвом, 3 конкретними господарюючими суб'єктами, які будуть на тільки базами практик, а й місцем роботи майбутніх фрахівців. Тому одним із завдань статті $€$ висвітлення переваг дуального навчання у вищих навчальних закладах та проблемних «вузьких» місць, які впливатимуть на підвищення ризиків при впровадженні дуального навчання у ВН3. 
Основоположниками дуальної системи освіти була Німеччина. У кінці XIX - на початку XX ст. під впливом соціально-економічних й соціокультурних перетворень в західноєвропейській педагогіці у Німеччині виник ресрорматорський рух за трудову школу, видатним діячом якого був Георг Кершенштейнер (1854-1932) - рефрорматор профресійної освіти в Німеччині. Пріоритетним напрямком роботи народної школи він бачив загальну трудову підготовку до профресійної діяльності. Для молодих працівників ним були започатковані додаткові школи, які давали загальноосвітню підготовку, пов'язану 3 професією підлітка. Власники фрабрик та майстерень зобов'язані були звільняти працівників підліткового віку для шкільного навчання (8-10 годин в тиждень) зі збереженням зарплати. Саме Г. Кершенштейнер заклав нову систему фрабрично-заводського навчання, яка поєднувала практичну роботу на виробництві з теоретичним навчанням. Ця система стала відомою у багатьох країнах Європи як німецька система дуальної професійної освіти $[9$, с. 56]. Таким чином XX століття в Німеччині було відзначено введенням дуальної системи у професійне навчання.

Дуальність як методологічна характеристика передбачає взаємодію освітньої підготовки фрахівців конкретного профрілю та господарюючої сорер, побудованих на єдиних основах узгодженості. У кінці 60-х на початку 70-х років ця система в Німеччині була перенесена і на вищі спеціалізовані навчальні заклади (Fachhochschulen). Слід зазначити, що шкільна система навчання має складову профресійного навчання, яку в межах дуальної освіти контролює держава.

Особливістю дуальної освіти $є$ провідна роль приватного капіталу, а не держави у підготовці фрахівців. Навчання за дуальною системою освіти передбачає першочерговий відбір претендентів роботодавцями: випускники шкіл повинні звертатись до місцевих відомств $з$ праці або конкретно на підприємство, де після екзамену, спеціального тестування, вивчення атестату, бесіди з психологом з підприємства приймається рішення про подальше навчання за цим фрахом або пропонуються інші варіанти за іншими спеціальностями. Таким чином підприємці заздалегідь формують для себе необхідні перспективні кадри. Така система не тільки має зазначені позитивні моменти, вона ще регулює ринок спеціалістів та перестраховує від переповнення непотрібними на певний момент часу фрахівцями, як це відбувається в Україні. Сучасний вітчизняний ринок праці переповнений економістами, юристами та відзначений десріцитом інженерів, медиків та ін.

Дуальна система навчання передбачає розробку та підписання «Договору про виробниче навчання» між абітурієнтом, майбутнім студентом, та власником підприємства або керівником установи. Зазначений договір повинен відображати такі основні моменти, як «мету навчання, вид трудової діяльності після закінчення навчання, спосіб, зміст, початок та тривалість навчання, навчальні заходи поза підприємством, тривалість робочого дня, тривалість випробувального терміну, розмір та терміни виплати зарплати, тривалість відпустки, умови, за яких договір може бути розірваним. Договір повинен гарантувати планомірне та раціональне навчання за обраною професією та захищати учня від незаконних дій з боку власника підприємства [9, с. 76]. Нагляд за виробничим навчанням, проведення іспиту та присвоєння робочої кваліфрікації здійснюють торгово-промислові палати, які реєструють договори про виробниче навчання та визначають, чи має підприємство кадри й умови, щоб забезпечити повноцінне навчання.

Отримуючи професійну освіту на підприємствах, молодь на практиці набуває фрахові компетентності для подальшої роботи. Враховуючи оптимальну передачу професійного досвіду, виробничу атмосферу на виробництві, молоді люди піднімаються на вищу, порівняно із загальноосвітньою школою ступінь профресійної соціалізації.

Систематичне застосування теоретичних знань на практиці дає можливість здобувачам освіти переносити відомі їм способи дій у нові ситуації, відкривати нові способи діяльності, критично мислити, виробляти власну життєву позицію, бачення тих чи інших виробничих процесів. Механізми самореалізації, саморозвитку, закладені у молоді під час дуального навчання, спілкування з майстрами-наставниками, співпраця у трудовому колективі сприяють становленню особистості, здатної без сторонньої допомоги розв'язувати пізнавальні задачі 3 метою подальшого перетворення і удосконалення навколишньої дійсності. Це дає можливості краще розв'язувати проблеми у реальних життєвих ситуаціях. Підприємства виграють від системи дуальної підготовки ще у тому, що після закінчення навчання робітників можна відразу залучати до виробництва, 
відпадає необхідність тривалого адаптаційного періоду. Згідно даних Г. Брауна, віце-президента Федерального об'єднання німецької спілки роботодавців (Bundesvereinigung der Deutschen Arbeitsgeberverbände), більш ніж 24000 німецьких підприємств співпрацюють з вищими навчальними закладами у межах дуальної освіти. Представники підприємств залучаються до роботи комісій з акредитації ВН3 з метою перевірки якості освіти та надання практичних порад щодо покращення освітніх послуг [10, с. 602].

Таким чином, німецька система дуальної професійної освіти має велику історію успішного розвитку, визнана на міжнародному рівні, та $є$ передумовою економічної продуктивності країни, адже успішна профресійна освіта призводить до збільшення шансів у майбутньому як для молоді, так і для економіки країни в цілому. Дуальна освіта в Німеччині дає кращі можливості для отримання кваліфікації, так як $€$ основним джерелом формування молодого покоління кваліфікованих робітників та завдяки тісному зв'язку зі сферою праці забезпечує оптимальний старт до трудового життя.

Сучасний вітчизняний ринок праці потребує молодого фрахівця - освіченого випускника вишу з конкретними практичними навичками. Наближення процесу навчання до конкретних вимог сучасного ринку праці може відбутися лише через включення до навчального процесу фрундаментальної, глибокої практичної підготовки, зокрема дуальної освіти у вищих закладах освіти. Нажаль поняття «дуальна система освіти» до недавно ототожнювалась лише з системою підготовки випускників професійно-технічних освітніх закладів.

Підготовка фрахівця у виші не може відповідати сучасним вимогам, якщо під час навчання студент опановує тільки теоретичні знання та вміння й у нього не формується готовність до самостійної практичної діяльності. Випускники вищих закладів освіти, які не мають достатньо сорормованих професійних компетенцій і досвіду практичної діяльності зазнають труднощів у працевлаштуванні. Проблема полягає у неузгодженості між профресійним навчальним закладом та потенційним роботодавцем (підприємством, організацією) [11, с. 18].

Дуальна система забезпечує рівновагу між попитом і пропозицією фрахівців на ринку праці. Адже співпраця освітніх і господарських суб'єктів передбачає підготовку саме тієї кількості фрахівців і такої якості знань та вмінь, якої в певний час потребує ринок праці $[12$, с. 6].

При дуальній системі навчання виробнича (практична частина) повинна становити близько 60-70\% часу навчального процесу, а теоретичне навчання у навчальному закладі 30-40\%. Така система широко практикується в Австрії та Швейцарії. Слід зазначити що курсові проекти, які виконують студенти, - це розробки, дослідження для конкретних замовників - роботодавців. Таким чином, курсові проекти мають конкретне практичне застосування, а університети додаткові кошти за рахунок оплати замовлень. В Україні дуальна система підготовки фрахівців тільки починає впроваджуватися в сучасну вітчизняну освіту. Безперечно, що при інтеграції наукового, виробничого та освітнього процесів доведеться зіткнутися 3 організаційними, науковометодичними та іншими труднощами: організації навчання, створення принципово нових навчальних планів, а основне - налагодження відносин із підприємствами, установами, малим бізнесом.

Положення про дуальне навчання в ЦДПУ ім. Винниченка має визначати два види дуального навчання: групове (передбачене навчальним планом і графріком навчального процесу) та індивідуальне (за заявками підприємств для певної кількості студентів за конкурсом).

Одним 3 основних інструментів стратегічного управління, що оцінюють в комплексі внутрішні і зовнішні чинники, які впливають на розвиток будь-якого господарюючого суб'єкта $€$ SWOT-аналіз [13, с. 34]. SWOT-аналіз дає можливість встановити взаємозв'язки між слабкими та сильними сторонами, між ризиками і можливостями зовнішнього середовища. У таблиці 1 наведено сильні й слабкі сторони впровадження дуального навчання в ЦДПУ імені Володимира Винниченка.

У таблиці 2 наведено можливості й ризики впровадження дуальної освіти. Це своєрідна розвідка, яка дозволяє оцінити ситуацію поза межами закладу, визначитися 3 можливостями, спрогнозувати та оцінити виклики.

Для зіставлення сильних і слабких сторін освітнього закладу з можливостями і ризиками ринку освітніх послуг та узагальнення результатів SWOT-аналізу застосовується матриця SWOT, яка має наступний вигляд (рис. 1)

На перетинах складових груп фракторів фрормуються поля, для яких характерні певні сполучення, їх треба враховувати у ході розробки стратегій. Поле СіМ передба- 


\section{SWOT-аналіз (загальні характеристики сильних і слабких сторін) впровадження дуального навчання на магістратурі в ЦдПУ імені Володимира Винниченка}

\begin{tabular}{|c|c|}
\hline $\begin{array}{c}\text { Потенційні внутрішні переваги } \\
\text { (сильні сторони) }\end{array}$ & $\begin{array}{r}\text { Потенційні в } \\
\text { (сла }\end{array}$ \\
\hline $\begin{array}{l}\text { навчання регулюється принципами ринкової } \\
\text { економіки; } \\
\text { зростання попиту на ринку праці на } \\
\text { випускників університету, які навчалися за } \\
\text { дуальною фрормою; } \\
\text { підвищення якості підготовки кадрів } \\
\text { та відповідність вимогам сучасного ринку } \\
\text { праці та роботодавців; } \\
\text { тісна співпраця між вишем і бізнес- } \\
\text { спільнотою (розроблення стандартів, } \\
\text { навчальних планів і програм, оцінювання } \\
\text { програмного результату навчання, забез- } \\
\text { печення робочих місць на підприємствах); } \\
\text { взаємовигода: держава, заклади вищої } \\
\text { освіти, підприємства та студенти; } \\
\text { мотивація майбутніх студентів до навчання } \\
\text { та отримання профресійних компетентностей; } \\
\text { підвищення престижу освіти в університеті за } \\
\text { обраними спеціальностями }\end{array}$ & $\begin{array}{l}\text { відсутність нормативно-правового } \\
\text { забезпечення дуальної фрорми навчання; } \\
\text { недосконалість, застарілість матеріально- } \\
\text { технічної бази; неповна готовність викладачів } \\
\text { до запровадження дуальної фрорми навчання; } \\
\text { складність пошуку роботодавців та } \\
\text { укладання угод із ними; } \\
\text { небажання роботодавців укладати угоди } \\
\text { з абітурієнтами до початку їхнього навчання; } \\
\text { значні часові та фінансові витрати для } \\
\text { оновлення інорормаційно-технологічного } \\
\text { забезпечення; } \\
\text { необхідність спеціальної підготовки майстрів } \\
\text { на виробництві; } \\
\text { недосконалість механізмів реалізації } \\
\text { багатоканального фрінансування } \\
\text { (в університеті та на потенційному } \\
\text { підприємстві, установі) }\end{array}$ \\
\hline
\end{tabular}

Джерело: розроблено авторами на основі [14, с. 616]

Таблиця 2

SWOT-аналіз (загальні зовнішні можливості та ризики) впровадження дуального навчання в ЦдПУ імені Володимира Винниченка)

\begin{tabular}{|c|c|}
\hline $\begin{array}{l}\text { Потенційні зовнішні можливості } \\
\text { (можливості, що відкриваються } \\
\text { завдяки дуальному навчанню) }\end{array}$ & $\begin{array}{c}\text { Потенційні зовнішні ризики } \\
\text { (пов'язані з реалізацією дуального } \\
\text { навчання) } \\
\end{array}$ \\
\hline $\begin{array}{l}\text { удосконалення матеріально-технічної } \\
\text { бази; } \\
\text { свідоме обрання спеціальності; } \\
\text { скорочення безробіття серед молоді; } \\
\text { підвищення конкурентоспроможності } \\
\text { ЦДПпу імені Володимира Винниченка; } \\
\text { упровадження в навчально-виробничий } \\
\text { процес інноваційних педагогічних } \\
\text { технологій, методів та прийомів; } \\
\text { подолання розриву між теорією й } \\
\text { практикою у навчально-виробничому } \\
\text { процесі }\end{array}$ & $\begin{array}{l}\text { скорочення обсягу контингенту студентів } \\
\text { у закладах в університеті; } \\
\text { зникнення деяких спеціальностей у зв'язку з } \\
\text { перенасиченням ринку ними та економічною } \\
\text { нестабільністю ситуації в Україні; } \\
\text { відмова підприємства фрінансувати підготовку } \\
\text { майбутніх фахівців; } \\
\text { зменшення державного фрінансування; } \\
\text { низький рівень зацікавленості підприємств } \\
\text { у співпраці з університетами щодо дуальної } \\
\text { форми навчання; } \\
\text { поступове зменшення часу на теоретичну } \\
\text { освітню підготовку }\end{array}$ \\
\hline
\end{tabular}

Джерело: розроблено авторами на основі [14, с. 616]

чає розробку стратегій підтримки та розвитку сильних сторін закладу щодо реалізації можливостей зовнішнього середовища; поле Сіз орієнтує стратегію на боротьбу із ризиками за допомогою використання внутрішніх резервів; поле СлМ спрямовує дії вишу на використання можливостей для подолання слабких сторін його внутрішнього потенціалу; поле Слз передбачає розробку такої стратегії, яка б дала змогу ЦДПУ імені Володимира
Винниченка не тільки зміцнити свій потенціал, а й відвернути можливі ризики у зовнішньому середовищі [13, с. 221].

SWOT-аналіз дозволяє систематизувати проблемні ситуації; краще розуміти структуру ресурсів, на які слід опиратися в удосконаленні діяльності та розвитку університету на перспективу; відстежувати загальний стан зовнішнього бізнес-середовища; виділяти і використовувати нові потенційні можливості 


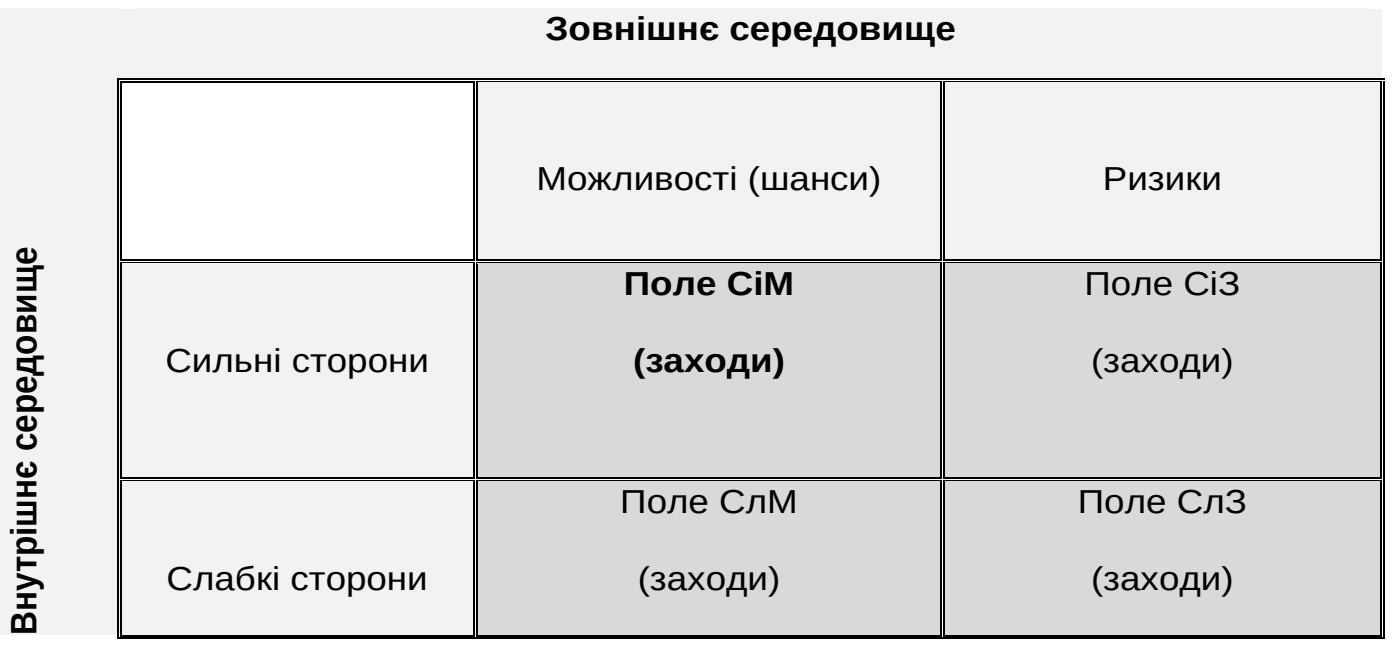

Рис. 1. Матриця SWOT

Джерело: розроблено авторами на основі [14, с. 616]

швидше, ніж конкуренти; вибрати оптимальний напрямок розвитку і уникнути ризиків. Правильно і вчасно прийняті стратегічні рішення сьогодні успішна діяльність закладу вищої освіти в майбутньому. Саме вони роблять вирішальний вплив на конкурентоспроможність освітніх послуг і нашого університету в цілому.

Розробка інноваційної політики ЦДПУ імені Володимира Винниченка щодо впровадження дуального навчання має суттєві особливості: виш $є$ виробником особливого виду продукції - освітніх послуг і програм, а розвиток освіти в силу відомих причин має носити випереджальний характер порівняно 3 іншими галузями.

Ефрективність впровадження дуального навчання у виші залежить від якості й опрацьованості організаційно-економічного механізму її реалізації, злагодженості роботи кожної ланки. Забезпечити таку злагодженість досить проблематично, зокрема, через ускладнення взаємовпливу маркетингу, науки, освіти і виробництва. Тільки чітка організація взаємодії може забезпечити цілісність і безперервність процесу дуальної освіти, дати необхідне скорочення термінів засвоєння інноваційних результатів і отримання різного роду есректів.

Механізм реалізації дуальної освіти в університеті повинен бути націлений на забезпечення активізації інноваційної діяльності, іiї злагодженості на всіх етапах інноваційного циклу, при цьому головним чинником інноваційного навчання $є$ людський капітал 3 його інтелектуальною активністю, творчою, креативною природою.
Аналізуючи різні підходи до фрормування інноваційної політики, слід зробити висновок, що більшість освітніх установ використовують емпіричні підходи, засновані на власному досвіді та аналізі дій конкурентів, а також інтуїції осіб, що приймають управлінські рішення. Тим часом $€$ необхідною розробка системи принципів, які рекомендується використовувати вишам при визначенні власної інноваційної політики. Концепція заснована на наступних фрундаментальних положеннях: орієнтація на споживача; безперервне удосконалення освітнього процесу і діяльності 3 метою підвищення якості освіти; комплексне і системне вирішення завдань забезпечення якості освіти на стадіях життєвого циклу підготовки фрахівця; зміщення головних зусиль у сторону людських ресурсів.

На формування інноваційної політики університету впливають стан інноваційної політики, яка реалізується на державному і регіональному рівнях, цільові орієнтири країни, а також споживачі результатів інноваційної діяльності вишу. Інноваційні відносини Цдпу імені Володимира Винниченка 3 державою вибудовуються в контексті вище вказаних цільових орієнтирів і відповідно до механізму срінансування інноваційної діяльності. Вплив регіональних особливостей на інноваційну політику вишу проявляється у специфріці ії напрямків і змісту. Зміст інноваційної політики університету тісно пов'язаний із середньостроковими Програмами розвитку області та освіти в цілому.

Механізм включає в себе організаційну та економічну складові. Організаційний механізм складається 3 елементів організацій- 
ного, кадрового, науково-методичного та інорормаційного забезпечення. Економічний механізм включає в себе елементи: прогнозування, поточного і перспективного планування, фрінансування, кредитування, податкові пільги, ціноутворення надання освітніх послуг, стимулювання.

Механізм реалізації інноваційної політики дуального навчання вишу являє собою сукупність форм, принципів, методів, базових категорій. За допомогою яких здійснюється:

- створення в університеті сприятливої внутрішньої економічної обстановки для ведення інноваційної діяльності в області дуальних освітніх послуг;

- узгодження економічних інтересів учасників дуального навчання;

- удосконалення системи управління вишом;

- підвищення конкурентоспроможності та інвестиційної привабливості ЦДПУ імені Володимира Винниченка на внутрішньому і зовнішньому ринках.

Методологічний підхід до побудови та фрункціонування даного механізму полягає у наступному:

- на основі застосування об'єктивних економічних законів і закономірностей, виявлених при фрормуванні соціально-економічної політики держави виробляється інноваційна політика вишу впровадження дуальної освіти;

- розробка державної інноваційної політики тягне за собою уточнення концепцій, стратегій, програм і планів розвитку освіти, науки та інновацій; законів та інших нормативних документів, що регулюють фрункціонування вишів, наукових та інноваційних організацій;

- розроблена концептуальна і нормативна база використовується вишами для вироблення альтернативних інноваційних стратегій з подальшою реалізацією кращої 3 них;

- аналіз альтернативних інноваційних стратегій полягає в базових категоріях інноваційної політики, принципах і методах її реалізації.

Механізм реалізації дуального навчання покликаний забезпечити об'єднання різних елементів в єдине ціле i, з позицій системного підходу, який $є$ одним з принципів системи менеджменту якості: пов'язати процеси фрормування, реалізації інноваційної політики та оцінки її ефективності.

Основні етапи реалізації Концепції дуального навчання на II (магістерському) рівні у ЦДПУ імені Володимира Винниченка:
I підготовчий етап. Розроблення нормативно-правової бази для запровадження дуальної освіти у повному обсязі (термін реалізації 1 рік).

II організаційний етап (визначення чітких траєкторій навчання за всіма спеціальностями). Розробка типових моделей дуальної форми здобуття освіти у ЦДПУ імені Володимира Винниченка (складання розкладу, графріку навчального процесу, заходів щодо оцінки результатів навчання). Пілотування моделей. Оцінка ефективності (термін реалізації - 2 роки).

III заключний етап. Створення кластерів дуальної освіти на базі ЦДПУ імені Володимира Винниченка та зацікавлених суб'єктів господарювання. Навчання почергово у виші та на виробництві або в установі, із поступовим заглибленням студентів у виробничу сореру (термін реалізації - 3 роки).

Такі зміни потребують перегляду структури освітніх програм, при цьому необхідно зазначити, що Закон «Про вищу освіту» надає університетам право самостійно розробляти освітні програми відповідно до кваліфікаційних вимог. Тому слід переглянути освітньо-професійні програми і внести корективи, щодо підготовки фрахівців за дуальною фрормою навчання, фрормування у них необхідних компетентностей та програмних результатів навчання, які потрібні сучасному підприємству, можливо, виходячи за межі існуючих галузевих стандартів. 3 урахуванням сучасних вимог галузевого ринку, освітні програми повинні бути інноваційно-технологічними, за замовленням підприємства, що забезпечить швидку адаптацію фахівця в робочий ритм підприємства.

Висновки. Таким чином, до переваг дуального навчання слід віднести: формування під час навчання фахових компетентностей у студентів з урахуванням особливостей роботи конкретного підприємства; випускники вишу матимуть можливість по закінченню навчання влаштуватися на роботу на підприємствахбазах практики, з якими ЦДПУ імені Володимира Винниченка укладатиме договори; використання системи договорів між студентами магістратури та підприємствами, яка сприяє навчанню молодих фахівців за спеціальним навчальним планом у межах безперервного освітнього процесу; випускник при подальшому працевлаштуванні не потребує психологічної та профресійної адаптації, що позитивно впливає на загальні результати діяльності підприємств. 
Реалізація дуального навчання в системі підготовки галузевих кадрів, в цілому сприятиме переходу на якісно новий рівень підготовки висококваліфікованих конкурентоздатних фрахівців. Але одночасно слід звернути увагу на проблемні місця впровадження ризику дуального навчання у виші: відсутність вітчизняного досвіду, методики об'єднання теоретичного та практичного навчання, і основне - недосконалість та нестабільність вітчизняного ринку праці, повна неготовність баз практики до таких інноваційно-інтеграційних процесів у вищій освіті, небажання співпраці та відповідальності за підготовку молодих кадрів.

\section{СПИСОК ВИКОРИСТАНИХ ДЖЕРЕЛ:}

1. Абашкіна Н.В. Принципи розвитку професійної освіти в Німеччині: монографрія. Київ : Вища школа, 1998. 207 c.

2. Амеліна С.М. Особливості дуальної системи вищої просресійної освіти у навчальних закладах Німеччини. Зб. наук. праць “Проблеми трудової і профресійної підготовки”. 2010. Вип. 15. С. 107-112.

3. Мілл. У. Дуальне навчання: досвід Німеччини. Олена Давліканова, Ніна Світайло (ред. та допов.). Маркетинг в Україні. 2016. № 6. С. 53-62.

4. Бегма О. На виробництво - вже підготовленим. 2018. Сільські вісті. 15. URL: http://www.silskivisti.kiev.ua/ 19562/index.php?n=38199 (дата звернення 20.03.2021).

5. Gren L., Panfilov Y., Karlyuk S. Directions in dual form of training introduction at National Technical University «Kharkiv Polytechnic Institute»: state-managerial aspect. Теорія і практика управління соціальними системами: фрілософрія, психологія, педагогіка, соціологія. 2019. № 1. С. 66-80.

6. Кримчак Л.Ю. Система дуальної освіти як умова якісної підготовки конкурентоспроможних професіоналів до ринку праці в Україні. 2019. URL: http://www.innovpedagogy.od.ua/archives/2019/11/part_2/20.pdf (дата звернення 20.03.2021).

7. Кулалаєва H.B. SWOT-аналіз упровадження елементів дуальної фоорми навчання в профресійну підготовку майбутніх кваліфікованих робітників. Науковий вісник Інституту професійно-технічної освіти НАПН України. Професійна педагогіка : зб. наук. праць. 2018. Вип. 15. С. 51-59.

8. Яковенко, К. В. Реалізація дуальної системи освіти в підготовці майбутніх фрахівців з інсоормаційних технологій. 2016. URL: http://repository.kpi.kharkov.ua/bitstream/KhPIPress/25362/1/Elita_2016_45_1 (дата звернення 20.03.2021)

9. Батышева С.Я. Профессиональная педагогика: Учебник для студентов, обучающихся по педагогическим специальностям и направлениям. Москва : Ассоциация «Профессиональное образование», 1997. 512 с.

10. Braun G. Das Studium muss besser auf den Beruf vorbereiten. WISU-Magazin. 2009. № 5. S. 601-602.

11. Левицкий Ю.В. Становление целостности образования, науки и производства в информационном обществе: авторефр. дисс. д-ра фрилос. наук: 09.00.01. Омск, 2007. 30 с.

12. Амоша О.І., Землянкін А.І., Моїсєєв Г.В. Сучасні підходи щодо здійснення взаємодії академічної науки, освіти і промислового виробництва. Економіка та держава. 2007. № 3. С. 4-7.

13. SWOT-аналіз - основа формування маркетингових стратегій: Навчальний посібник / За ред. Л.В. Балабанової. Київ : Знання, 2005. 301 с.

14. Економічний аналіз : Підручник для студентів економічних спеціальностей ВНЗ / За ред. Ф.Ф. Бутинця. Житомир: ПП «Рута», 2007. 704 с.

\section{REFERENCES:}

1. Abashkina N.V. (1998) Pryncypy rozvytku profesijnoji osvity v Nimechchyni. [Principles of development of vocational education in Germany]: monoghrafija. Kyiv: Vyshha shkola, 207 p.

2. Amelina S.M. (2010) Osoblyvosti dualjnoji systemy vyshhoji profesijnoji osvity u navchaljnykh zakladakh Nimechchyny. [Features of the dual system of higher professional education in educational institutions in Germany]. Zb. nauk. pracj "Problemy trudovoji i profesijnoji pidghotovky", vol. 15, pp. 107-112.

3. Mill U. (2016) Dualjne navchannja: dosvid Nimechchyny [Dual learning: the experience of Germany]. Olena Davlikanova, Nina Svitajlo (red. ta dopov.). Marketyngh v Ukrajini, no. 6, pp. 53-62.

4. Begma O. (2018) For production - already prepared. Village news, 15. Available at: http://www.silskivisti.kiev.ua/ 19562/index.php?n=38199 (accessed 21 May 2021).

5. Gren L., Panfilov Y., Karlyuk S. (2019) Directions in dual form of training introduction at National Technical University «Kharkiv Polytechnic Institute»: state-managerial aspect. Teorija $i$ praktyka upravlinnja socialjnymy systemamy: filosofija, psykhologhija, pedaghoghika, sociologhija, no. 1, pp. 66-80. 
6. Krymchak L.Ju. (2019) Systema dualjnoji osvity jak umova jakisnoji pidghotovky konkurentospromozhnykh profesionaliv do rynku praci v Ukrajini [Dual education system as a condition for qualitative preparation of competitive professionals in the labor market in Ukraine]. Available at: http://www.innovpedagogy.od.ua/archives/2019/11/ part_2/20.pdf (accessed 25 May 2021).

7. Kulalajeva N.V. (2018) SWOT-analiz uprovadzhennja elementiv dualjnoji formy navchannja v profesijnu pidghotovku majbutnikh kvalifikovanykh robitnykiv [SWOT-analysis of the introduction of elements of the dual form of education in the training of future skilled workers]. Naukovyj visnyk Instytutu profesijno-tekhnichnoji osvity NAPN Ukrajiny. Profesijna pedaghoghika: zb. nauk. prac, vol. 15, pp. 51-59.

8. Yakovenko K.V. (2016) Realizacija dualjnoji systemy osvity v pidghotovci majbutnikh fakhivciv z informacijnykh tekhnologhij [Implementation of a dual education system in the training of future IT professionals]. Available at: http://repository.kpi.kharkov.ua/bitstream/KhPIPress/25362/1/Elita_2016_45_1_Yakovenko_Realizatsiia.pdf (accessed 20 May 2021).

9. Batysheva S.Ja. (1997) Professyonaljnaja pedaghoghyka [Professional pedagogy]: Uchebnyk dlja studentov, obuchajushhykhsja po pedaghoghycheskym specyaljnostjam y napravlenyjam. Moscow: Assocyacyja «Professyonaljnoe obrazovanye», $512 \mathrm{p}$.

10. Braun G. (2009) Das Studium muss besser auf den Beruf vorbereiten. WISU-Magazin, no. 5, pp. 601-602.

11. Levyckyj Ju.V. (2007) Stanovlenye celostnosty obrazovanyja, nauky y proyzvodstva $v$ ynformacyonnom obshhestve [Formation of the integrity of education, science and production in the information society]: avtoref. dyss. d-ra fylos. nauk: 09.00.01. Omsk,. $30 \mathrm{p}$.

12. Amosha O.I., Zemljankin A.I., Mojisjejev Gh.V. (2007) Suchasni pidkhody shhodo zdijsnennja vzajemodiji akademichnoji nauky, osvity i promyslovogho vyrobnyctva [Modern approaches to the interaction of academic science, education and industrial production]. Ekonomika ta derzhava, no. 3, pp. 4-7.

13. Balabanovoji L.V. (Ed.) (2005) SWOT-analiz - osnova formuvannja marketynghovykh strateghij [SWOTanalysis - the basis for the formation of marketing strategies]: Navchaljnyj posibnyk. Kyiv: Znannja, $301 \mathrm{p}$.

14. Butynecj F.F. (Ed.) (2007) Ekonomichnyj analiz [Economic analysis]: Pidruchnyk dlja studentiv ekonomichnykh specialjnostej VNZ. Zhytomyr: PP «Ruta», 704 p. 